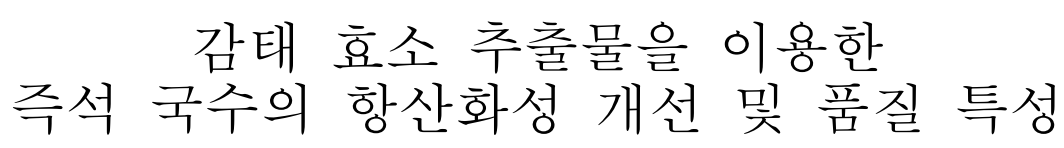

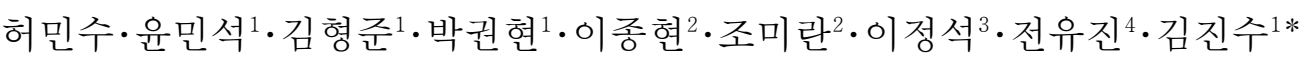
경상대학교 식품영양학과/해양산업 연구소, ${ }^{1}$ 경상대학교 해양식품공학과/해양산업연구소

${ }^{2}$ (주)신천지식품, ${ }^{3}$ 제주-씨그랜트 사업단, ${ }^{4}$ 제주대학교 해양의생명과학부

\title{
Improvement on the Antioxidant Activity of Instant Noodles Containing Enzymatic Extracts from Ecklonia cava and Its Quality Characterization
}

\author{
Min Soo Heu, Min Seok Yoon ${ }^{1}$, Hyung Jun Kim¹, Kwon Hyun Park', \\ Jong Hyun Lee ${ }^{2}$, Mi Ran Jo², Jung Suk Lee, You Jin Jeon ${ }^{4}$ and Jin-Soo Kim ${ }^{1 *}$ \\ Department of Food Science and Nutrition/Institute of Marine Industry, \\ Gyeongsang National University, Jinju 660-701, Korea \\ ${ }^{1}$ Department of Seafood Science and Technology/Institute of Marine Industry, \\ Gyeongsang National University, Tongyeong 650-160, Korea \\ ${ }^{2}$ Sinchungeefood Co. Ltd., Jeju 690-012, Korea \\ ${ }^{3}$ Jeju Sea Grant College Program, Jeju 690-756, Korea \\ ${ }^{4}$ School of Marine Biomedicinal Sciences, Jeju National University, Jeju 690-120, Korea
}

This study was conducted to improve the antioxidative activity of instant noodles containing enzymatic extracts from Ecklonia cava (EEC). EEC has relatively better antioxidative activity than extracts from other indigenous plants in Jeju Island. The EEC $(2.5 \mathrm{mg} / \mathrm{mL})$ had $82.5 \%$ for the hydroxy radical, $78.4 \%$ for the DPPH radical, and $64.9 \%$ for the superoxide anion radical scavenging activities, and $65.2 \%$ for the cell viability $(100 \mu \mathrm{g} / \mathrm{mL})$. According to the texture of the dough, the DPPH free radical scavenging of uncooked instant noodles, sensory evaluation of cooked instant noodles, and turbidity of the cooking drip, the optimal EEC concentration was $1.8 \%$ for the instant noodles. The major amino acids in the instant noodles with EEC were glutamic acid (24.2\%), proline $(10.2 \%)$, valine $(10.0 \%)$, and isoleucine $(12.3 \%)$. The zinc and iron in the instant noodles were enhanced by adding 1.5-1.8\% EEC. The antioxidant activity of instant noodles with EEC was $75.4 \%$ for the hydroxy radical, $74.1 \%$ for the DPPH radical, and 51.2 $\%$ for the superoxide anion radical scavenging activities.

Key words: Instant noodle, Ecklonia cava, Seaweed, Functional foods

서 론

최근 경제수준의 향상과 함께 최근 소비자들의 기호가 고급 화, 간편화 및 건강화를 지향하면서 식생활에도 많은 변화를 가져와 기능성이 강화된 건강식품이 각광을 받고 있다. 식품 에 대한 소비자들의 이러한 경향은 면류에서도 예외가 아니어 서 면류 제품의 출시 경향도 양보다 품질, 편의성 및 건강 기능성의 개념이 반영된 건강지향적인 컨셉과 편의성을 생각 하는 제품들을 중심으로 시장을 형성하고 있다 (Park et al., 2003). 일반적으로 면은 가공방법과 형태에 따라 건면류, 생면 류, 숙면류, 유탕면류 및 파스타류 등으로 분류되고 있다 (Kim and Park, 2008; Kim, 2008). 이들 면 중 유탕면의 대표적인 제품이라 할 수 있는 라면은 우지파동과 유지 과량 섭취에 의한 비만 등으로 소비자 반응이 시들해지고, 이를 대체할 수 있는 고급스런 생면 및 숙면 제품들이 출시됨으로서 인스 턴트 라면을 빠르게 대체하고 있다. 2000년 이후 국내 라면시

\footnotetext{
*Corresponding author: jinsukim@gnu.ac.kr
}

장은 성장률이 정체되어 2003년부터 지금까지 약 1 조 5,000 억 에서 머물러 있지만, 생면과 숙면시장은 2000년 이후 매년 $20 \%$ 이상 성장하여 2007년 기준으로 약 3,000 억의 시장을 형성하고 있고, 이와 같은 패턴은 계속 지속될 전망이다 (Food News Co., 2009). 특히, 숙면류는 즉석에서 조리가 가능하고, 조리시간이 짧아 주중에 가정과 떨어져 생활하는 직장인이 간편하게 조리하여 식용하기 위하여 식용하고 있고, 휴게소나 편의점 등에서도 즉석식품으로서의 활용도가 급증하고 있다. 이러한 일면에서, 면류시장에서 점차 비중이 커지는 숙면의 시장 점유율을 보다 높이기 위해서는 기존 제품과 차별화된 기능성 강화식품의 개발이 요구되고 있다.

한편, 해조류는 육상식물에 비하여 생육하는 환경이 현저 한 차이가 있어 구성성분이 다르며, 풍부한 다당류를 함유하 고 있을 뿐만이 아니라 다양한 미네랄과 비타민이 풍부하게 함유되어 있고, 일부 특정 성분에서는 항균 (Nagayama et al., 2002), 항산화 (Heo and Jeon, 2005), 항고혈압 (Cha et al., 
2006) 및 항암활성 (Okai et al., 1998) 등의 건강기능특성을 가지고 있다. 이와 같은 해조류 중 감태 (Ecklonia cava)는 항산화성 (Kim and Lee, 2004)과 항고혈압성 (Yasantha and Jeon, 2005) 등과 같은 건강 기능성들이 밝혀짐으로서 새로운 건강 기능성 소재로서 부각되고 있으나, 아직 알긴산의 추출 소재와 같이 단순 이용되고 있어 이의 효율적 이용이 절실한 실정이다.

효소 추출법은 상업적 효소로 식물의 세포벽에 있는 섬유질 이나 당단백질 등의 고분자 물질을 분해시켜 생리활성물질이 원활히 추출될 수 있도록 유도하는 친환경적 추출법이다. 효 소 추출법은 열수 추출법이나 기타 추출법에 비하여 높은 수율의 저분자 수용화 기술이어서 효소 추출물이 가지고 있는 생리활성을 생체내로 쉽게 전달시킬 수 있고, 유기용매와 같 은 화학약품을 사용하지 않아 안전성에 대한 우려도 없어 기능성 천연소재로서 식품의 응용성이 매우 높을 것으로 기대 된다.

한편, 국수는 우리나라 사람들에게 밥 및 빵과 더불어 주식 에 해당하는 가공식품이어서 이에 대한 연구가 많다. 이 중 최근 소비자의 건강지향적인 식품 선호도를 고려하여 영양적 가치가 높고 건강 기능성을 갖는 다양한 원료들, 즉 율무 (Park, 1995), 김 (Lee et al., 2000), 버섯 (Kim et al., 2005), 홍삼 (Kim and Park, 2008), 마 (Park and Cho, 2006), 클로렐라 (Park and Cho, 2004), 손바닥선인장 (Lee et al., 1999), 구기자 (Lim et al., 2003), 녹차 (Park et al., 2003), 백년초 (Chong and Park, 2003), 홍화씨 (Kwak et al., 2002), 양파즙 (Lee and Shim, 2006), 송화 (Kim, 2005), 쑥 (Park and Kim, 2006) 등을 첨가하여 국수를 제조하고자 시도한 연구는 아주 많다. 하지 만, 이들 연구는 국수에 건강 기능성을 부여하기 위하여 원료 를 단순히 건조하여 분말로 사용하거나 열수 추출하여 그 액즙을 첨가한 정도에 불과하고, 감태를 소재로 하여 효소 추출하여 이용한 경우는 찾아볼 수가 없다.

본 논문에서는 효소추출공법으로 제조한 감태 효소 추출물 을 즉석 국수 제조시 적용함으로서 기능성이 부여된 고품질의 즉석 국수를 개발하고자 한다.

\section{재료 및 방법}

\section{감태 효소 추출물}

감태 (Ecklonia cava) 효소 추출물은 2009년 4월에 아쿠아그 린텍 (주) (제주시)로부터 구입하여 $-20^{\circ} \mathrm{C}$ 에 저장하여 두고 사용하였으며, 이 회사에서 제시한 감태 효소 추출물의 제조 공정은 다음과 같다. 감태 약 $100 \mathrm{~g}$ 을 증류수 $10 \mathrm{~L}$ 에 가하고, 시판 당분해효소인 Cellulast (Cellulast 1.5 L FG, Novozyme Nordisk Co.) $100 \mathrm{mg}$ 을 첨가하여 잘 혼합한 후 $\mathrm{pH} 4.5$ 및 $50^{\circ} \mathrm{C}$ 에서 24 시간 동안 추출한다. 이어서 추출물의 $\mathrm{pH}$ 를 7.0 으 로 조정하고 $100^{\circ} \mathrm{C}$ 에서 10 분간 가열하여 실활시킨 다음 원심 분리 (Corning US/PC 420, 3,000 rpm, 20분)시켜 잔사를 제거하 였다. 여과된 상층액은 membrane filter를 사용하여 분리한 후 진공농축한 다음 동결건조하여 제조하였다.
감태 효소 추출물 첨가 즉석 국수의 제조

감태 효소 추출물 첨가 즉석 국수의 제조를 위한 반죽은 중력분 (대한제분)을 $28.3 \%(\mathrm{w} / \mathrm{w})$, 박력분 (대한제분)을 $22.7 \%$ $(\mathrm{w} / \mathrm{w}$, 단 감태 효소 추출물 첨가 시료의 경우 $0.3 \%$ 단위로 $2.1 \%$ 까지 대체하여 첨가), 쌀가루 (남도상회)를 $5.7 \%(\mathrm{w} / \mathrm{w})$, 감자전분 (금등농수산)을 $5.1 \%(\mathrm{w} / \mathrm{w})$, 소맥전분 (신송식품)을 $2.8 \%(\mathrm{w} / \mathrm{w})$, 정제소금 (한주소금)을 $0.7 \%(\mathrm{w} / \mathrm{w})$, 정제수를 $34.7 \%(\mathrm{w} / \mathrm{w})$ 가 되게 각각 정확히 계량한 다음 반죽기에서 15 분 정도 반죽하여 제조하였다. 이어서 즉석 국수는 $120^{\circ} \mathrm{C}$ 로 가열한 자동 숙면기 (냉면기계)에 제조한 반죽을 넣고 둥근 면선 (직경: $0.8 \mathrm{~mm}$ )을 만들어 1 인분 $(150 \mathrm{~g}$ )씩 절단한 다음 냉각 컨테이너를 통과시키면서 환풍팬으로 약 4분 정도 냉각 한 다음 약간의 공기를 제거하면서 함기포장하여 제조하였다.

일반성분

감태 효소 추출물 및 이를 첨가한 즉석 국수의 일반성분 함량은 $\mathrm{AOAC}$ 법 (1995)에 따라, 수분은 상압가열건조법, 조단 백질은 semimicro Kjeldahl법, 조지방은 Soxhlet법으로, 회분은 건식회화법으로 측정하였고, 탄수화물은 100 - (수분 함량 + 조단백질함량 + 조지방 함량 + 회분 함량)으로 나타내었다.

\section{항산화 활성}

항산화성 강화 즉석 국수의 제조를 위한 감태 효소 추출물 의 적정 첨가농도 검색은 Lee and Shim (2006)이 언급한 방법 과 같이 spectrophotometer를 이용하는 DPPH free radical 소거 능으로 실시하였다. 즉, DPPH free radical 소거능은 에탄올에 용해시킨 $8 \times 10^{-5} \mathrm{M} \mathrm{DPPH}$ 용액 $2.9 \mathrm{~mL}$ 에 해당농도의 감태 효소 추출물 $0.1 \mathrm{~mL}$ 를 가하고 혼합하여 30 분간 반응시킨 후 $516 \mathrm{~nm}$ 에서 흡광도를 측정하고, 이를 토대로 계산하여 나타내 었다

감태 효소 추출물 및 이를 첨가하여 제조한 즉석 국수의 항산화 활성은 다음과 같이 시료를 조제하여 $\mathrm{ESR}$ spectroscopy (JES-FA 2300, Jeol, Japan)로 DPPH radical 소거 활성, hydroxyl radical 소거 활성 및 superoxide 소거 활성을 측정하였다. 항산화 활성의 측정을 위한 시료는 감태 추출물 을 $2 \mathrm{mg} / \mathrm{mL}$ 로 제조하여 사용하였고, 즉석 국수의 경우 즉석 국수 $50 \mathrm{~g}$ 에 증류수 $250 \mathrm{~mL}$ 를 첨가하고, $80^{\circ} \mathrm{C}$ 에서 2 시간 동안 교반하여 추출한 다음 원심분리 $(3,000 \mathrm{rpm}, 20$ 분) 및 여과하는 조작을 2회 반복한 후 그 여액을 진공동결건조하여 시료로 사용하였다.

감태 효소 추출물 및 이를 첨가한 즉석 국수의 DPPH radical 소거 활성은 Nanjo et al. (1996)의 방법에 따라 eppendorf tube $(1.7 \mathrm{~mL})$ 에 시료 용액 $(2 \mathrm{mg} / \mathrm{mL}) 30 \mu \mathrm{L}$ 와 메탄올에 용해한 $60 \mu \mathrm{M} \mathrm{DPPH}$ 용액 $30 \mu \mathrm{L}$ 를 각각 가하고, 상온에서 2.5 분 동안 반응시켜 capillary tube에 옮긴 다음 electron spin resonance (ESR) spectrometer (JES-PX 2300, JEOL, Japan)로 측정하였다. 이 때 $\mathrm{ESR}$ spectrophotometer의 측정조건은 magnetic field의 경우 $336.5 \pm 5 \mathrm{mT}$, microwave power의 경우 $5 \mathrm{~mW}$, modulation frequency의 경우 $9.41 \mathrm{GHz}$, modulation 
amplitude의 경우 $1 \times 1000$, sweep time의 경우 30 초이었고, 항산화 시료에 대한 DPPH free radical 소거 활성 (\%)은 (ESR signal intensity for medium containing the additives of concern/ESR signal intensity for the control medium) $\times 100$ 으로 계산하였다.

감태 효소 추출물 및 이를 첨가한 즉석 국수의 hydroxyl radical 소거 활성은 Rosen and Rauckman (1980)의 방법에 따라 이온 가수분해에 의하여 전이된 hydroxyl radical 양을 측정하여 나타내었다. 즉, $\mathrm{DMPO-OH}$ adduct를 측정하기 위하 여 eppendorf tube $(1.7 \mathrm{~mL})$ 에 시료 용액 $(2 \mathrm{mg} / \mathrm{mL})$ 과 radical trap 시약인 $0.3 \mathrm{M}$ DMPO (5,5-dimethylpyrrolin N-oxide)를 각 각 $20 \mu \mathrm{L}$ 씩 혼합하고 $10 \mathrm{mM} \mathrm{FeSO}$ 와 $10 \mathrm{mM} \mathrm{H}_{2} \mathrm{O}_{2}$ 를 각각 $20 \mu \mathrm{L}$ 씩 재혼합한 후 상온에서 2.5 분간 반응시켜 capillary tube에 옮긴 다음 electron spin resonance (ESR) spectrometer (JES-PX 2300, JEOL, Japan)로 측정하였다. 이 때 $\mathrm{ESR}$ spectrophotometer의 측정조건은 modulation width의 경우 0.1 $\mathrm{mT}$, amplitude의 경우 $1 \times 200$, microwave power의 경우 1 $\mathrm{mW}$, sweep width의 경우 $10 \mathrm{mT}$ 및 sweep time의 경우 30 $\mathrm{sec}$ 이었고, 항산화 시료에 대한 hydroxy radical 소거 활성 (\%) 은 (ESR signal intensity for medium containing the additives of concern/ESR signal intensity for the control medium) $\times 100$ 으 로 계산하였다.

감태 효소 추출물 및 이를 첨가한 즉석 국수의 superoxide anion radical 소거 활성은 Guo et al. (1999)의 방법에 따라 측정하였다. 즉, superoxide 소거 활성을 측정하기 위하여 eppendorf tube $(1.7 \mathrm{~mL})$ 에 시료 용액 $(2 \mathrm{mg} / \mathrm{mL}), 0.8 \mathrm{mM}$ riboflavin, $1.6 \mathrm{mM}$ EDTA (ethylemediaminetetraacetic acid) 및 $800 \mathrm{mM}$ DMPO (5,5-dimethyl-1-pyrroline N-oxide) $60 \mu \mathrm{L}$ 를 각각 넣고 혼합한 다음 반응 (365 nm UV lamp에서 1분)시켜 capillary tube에 옮긴 다음 electron spin resonance (ESR) spectrometer (JES-PX 2300, JEOL, Japan)로 측정하였다. 이 때 ESR spectrophotometer의 측정조건은 central field의 경우 $3475 \mathrm{G}$, modulation width의 경우 $0.1 \mathrm{mT}$, modulation amplitude 의 경우 $1 \times 1000$, microwave power의 경우 $10 \mathrm{~mW}$, scan width 의 경우 $10 \mathrm{mT}$ 이었고, 항산화 시료에 대한 hydroxy radical 소거 활성 (\%)은 (ESR signal intensity for medium containing the additives of concern/ESR signal intensity for the control medium) $\times 100$ 으로 계산하였다.

\section{세포활성}

Chinese hasmter lung fibroblast V79-4 cell (ATCC CCL-93, 미국 $\mathrm{ATCC}$ 에서 분양) 의 세포수가 well당 약 $1.5 \times 10^{4}$ 이 되도록 $96 \mathrm{well}$ 에 각각 접종한 후 17 시간동안 $37^{\circ} \mathrm{C}$ 로 조정된 $5 \% \mathrm{CO}_{2}$ 배양기에서 배양하고, 효소 추출물을 25,50 및 100 $\mathrm{ug} / \mathrm{mL}$ 의 농도로 처리한 후 다시 $37^{\circ} \mathrm{C}$ 로 조정된 $5 \% \mathrm{CO}_{2}$ 배양 기에서 재 배양 하였다. 이어서 $\mathrm{H}_{2} \mathrm{O}_{2}$ (stock $20 \mathrm{mM}$ )를 최종농 도가 $1 \mathrm{mM}$ 이 되도록 $10 \mu \mathrm{L}$ 씩 가한 후 다시 $37^{\circ} \mathrm{C}$ 로 조정된 $5 \% \mathrm{CO} 2$ 배양기에서 30 분간 배양하였다. 이와 같이 전처리한 well을 MTT 시약 (stock $2 \mathrm{mg} / \mathrm{mL}$ )을 $50 \mu \mathrm{L}$ 씩 가한 후 다시 $37^{\circ} \mathrm{C}$ 로 조정된 $5 \% \mathrm{CO}_{2}$ 배양기에서 4 시간 동안 배양하고, 원심 분리한 후 상층액을 제거한 다음 $\mathrm{DMSO}$ 를 $150 \mu \mathrm{L}$ 씩 가하여 혼합하고 $540 \mathrm{~nm}$ 에서 흡광도를 측정하여 세포 생존율을 구하 였다.

Hunter 색조

Hunter 색조의 측정을 위한 시료는 즉석 국수 제조용 반죽을 제면기 (20171, The Kitchen Collection Inc., Seattle, USA)로 두께가 $0.5 \mathrm{~cm}$ 가 되도록 제면한 다음 이를 두겹으로 겹쳐서 시료로 사용하였다.

색조는 두겹으로 겹친 제면을 시료로 하여 직시 색차계 (ZE 2000, Nippon Denshoku Industry Co., Japan)로 반죽 표면의 Hunter $\mathrm{L}, \mathrm{a}, \mathrm{b}$ 및 $\triangle \mathrm{E}$ 를 측정하였다. 이때 표준백판은 $\mathrm{L}$ 값이 $96.84, \mathrm{a}$ 값이 -0.40 및 $\mathrm{b}$ 값이 0.64 이었다.

\section{조리 특성 및 관능검사}

즉석 국수의 조리 특성은 아래에 설명하는 바와 같이 조리 면의 중량, 부피, 수분흡수율 및 국물의 투과도로 살펴보았다. 즉석 국수의 조리 특성 및 관능검사 검토를 목적으로 조리면 의 제조를 위하여 뚜껑이 있는 용기에 즉석 국수 $10 \mathrm{~g}$ 과 끓는 물 $30 \mathrm{~mL}$ 를 가하고 뚜껑을 닫은 다음 3 분간 조리한 후 건져서 냉수에 20초간 냉각 및 탈수하고 조리하여 조리 즉석 국수의 조리 특성 및 관능 특성 검토를 위한 조리면으로 사용하였다. 그리고, 이 때 발생한 조리면 자숙수는 국물의 투과도 측정을 위한 시료로 사용하였다.

조리면의 중량은 전처리한 조리면의 무게를 측정하여 그 무게로 나타내었고, 조리면의 부피는 $30 \mathrm{~mL}$ 의 증류수가 담긴 $50 \mathrm{~mL}$ 메스실린더에 조리면을 가하여 증가한 증류수의 부피 로 나타내었으며, 조리면의 수분 흡수율은 조리면의 제조에 사용한 생면의 중량에 대하여 조리면과 생면과의 무게차의 상대비율 $(\%)$ 로 나타내었다.

조리 자숙수의 탁도는 조리자숙수를 시료로 하여 분광광도 계 (UV-140-02, Shimadzu Co., Japan)로 $660 \mathrm{~nm}$ 에서 투과도를 측정한 다음 이의 투과도로 나타내었다.

감태 효소 추출물의 첨가 농도에 따른 즉석 국수의 관능검 사는 뚜껑이 있는 용기에 즉석 국수 $150 \mathrm{~g}$ 과 끓는 물 450 $\mathrm{mL}$ 를 가하고 뚜껑을 닫은 다음 3 분간 조리한 후 10 인의 panel member를 구성하여 감태 효소 무첨가 대조군을 기준점인 5점 으로 하고 조직감, 색도 및 맛이 이보다 우수한 경우 6-9점으 로, 그리고 이보다 열악한 경우 4-1점으로 하는 9점 척도법으 로 하여 평균값으로 나타내었다.

\section{총아미노산 및 무기질}

총 아미노산은 적정량의 시료 $(50 \mathrm{mg})$ 에 $6 \mathrm{~N} \mathrm{HCl} 2 \mathrm{~mL}$ 를 ampoule에 넣고, 밀봉한 후 가수분해 $\left(110^{\circ} \mathrm{C}, 24\right.$ 시간 $)$ 한 다음 glass filter로 여과, 감압건조 및 구연산나트륨 완충액 $(\mathrm{pH} 2.2)$ 으로 정용 $(25 \mathrm{~mL})$ 하여 시료를 조제한 다음 이의 일정량을 사용하여 아미노산 자동분석기 (Biochrom 30, Parmacia Biotech., England)로 분석하였다.

무기질은 Tsutagawa et al. (1994)이 실시한 방법에 따라 
질산으로 유기질을 습식 분해하여 시료를 조제한 다음 inductively coupled plasma spectrophotometer (ICP, Atomscan $25, \mathrm{TJA})$ 로 분석하였다.

\section{통계처리}

데이터의 통계처리는 ANOVA test를 이용하여 분산분석을 실시한 후 Duncan의 다중위검정으로 최소유의차 검정 $5 \%$ 유의수준)을 실시하여 나타내었다.

\section{결과 및 고찰}

감태 효소 추출물의 일반 성분 및 항산화 특성

즉석 국수의 항산화성 개선을 위한 감태 효소 추출물의 일반성분 함량은 Table 1 과 같다. 감태 효소 추출물의 일반성 분 함량은 수분 함량의 경우 $7.8 \%$, 조단백질 함량의 경우 $10.1 \%$, 조지방 함량의 경우 $1.4 \%$, 조회분 함량의 경우 $16.6 \%$ 를 나타내었고, 이를 토대로 하여 계산한 탄수화물 함량의 경우 $64.1 \%$ 를 나타내었다. 한편, Lee et al. (2006)은 건조 감태의 잎과 줄기의 항산화 활성을 비교하는 연구에서 이들의 일반 성분 함량은 수분 함량의 경우 각각 $5.7 \%$ 및 $10.8 \%$, 회분 함량의 경우 각각 $11.5 \%$ 및 $20.5 \%$, 조단백질 함량의 경우 각각 $14.2 \%$ 및 $7.7 \%$, 탄수화물 함량의 경우 각각 $66.2 \%$ 및 $59.5 \%$, 그리고 조지방 함량의 경우 각각 $2.6 \%$ 및 $1.7 \%$ 로 보고 한 바 있다. 이상의 일반성분 결과로 미루어 보아 본 실험에서

Table 1. Proximate compositions of dried Ecklonia cava and its enzymatic extracts

\begin{tabular}{cccc}
\hline \multirow{2}{*}{ Proximate } & \multicolumn{2}{c}{ Ecklonia cava $^{1)}$} & \multirow{2}{*}{$\begin{array}{c}\text { Ecklonia cava } \\
\text { extracts }\end{array}$} \\
\cline { 2 - 3 } composition & \multicolumn{1}{c}{ Leaf } & \multicolumn{1}{c}{ Stem } & \\
\hline Moisture & $5.7 \pm 0.3^{2)}$ & $10.8 \pm 0.3$ & $7.8 \pm 0.1$ \\
Crude protein & $14.2 \pm 0.2$ & $7.7 \pm 0.4$ & $10.1 \pm 0.1$ \\
Crude lipid & $2.6 \pm 0.1$ & $1.7 \pm 0.1$ & $1.4 \pm 0.0$ \\
Crude carbohydrate & $66.2 \pm 0.2$ & $59.5 \pm 0.3$ & $64.1^{3)}$ \\
Ash & $11.5 \pm 0.1$ & $20.5 \pm 0.4$ & $16.6 \pm 0.0$ \\
\hline
\end{tabular}

1) These data were quoted from Lee and Shim (2006).

2) Values are the means \pm standard deviation of three determination.

3) Carbohydrate $=100-($ moisture + protein + lipid + ash $)$

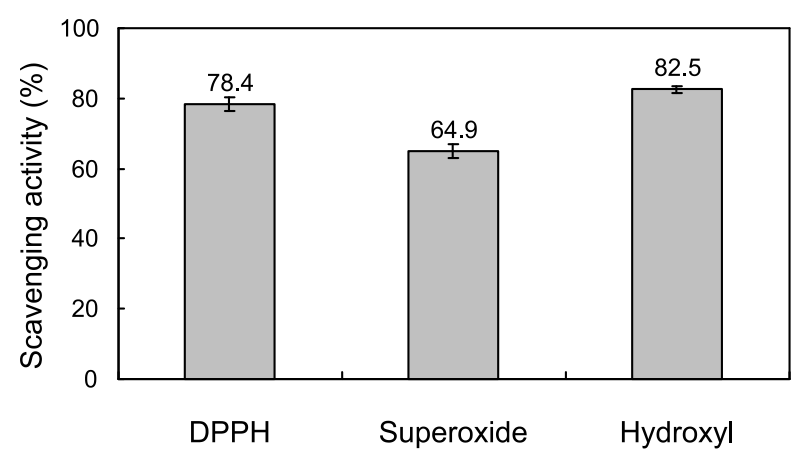

Fig. 1. DPPH radical scavenging, superoxide anion scavenging and hydroxyl radical scavenging activities of enzymatic extracts $(2.5 \mathrm{mg} / \mathrm{mL})$ from Ecklonia cava.

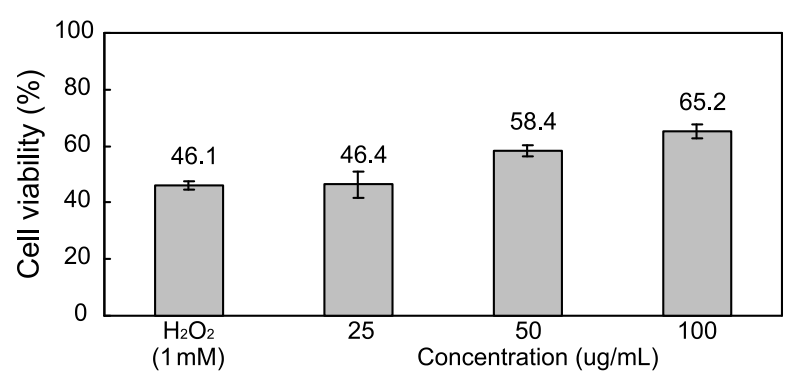

Fig. 2. Cell viability of enzymatic extracts from Ecklonia cava as affected by concentration.

Donryu rat liver cells were prepared and incubated with the enzymatic extracts from Ecklonia cava at the various concentrations. After $17 \mathrm{hr}$, cells were placed in DMED medium without serum and then incubated with $1 \mathrm{mM} \mathrm{t}$-BHP for $2.5 \mathrm{hr}$. MTT assay was used to measure cell viability.

제조한 감태 효소 추출물의 일반성분은 원료 감태의 일반성분 과 큰 차이가 없었고, 주성분은 탄수화물과 무기질로 판단되 었다.

$\mathrm{ESR}$ 을 이용하여 감태 효소 추출물의 DPPH radical, hydroxyl radical 및 superoxide anion radical의 소거 활성을 검토한 결과는 Fig. 1 과 같다. 감태 효소 추출물 $(2.5 \mathrm{mg} / \mathrm{mL})$ 의 항산화 활성은 hydroxy radical 소거 활성이 $82.5 \%$ 로 가장 우수 하였고, 다음으로 $\mathrm{DPPH}$ free radical 소거 활성 $(78.4 \%)$ 및 superoxide anion radical 소거 활성 $(64.9 \%)$ 의 순이었으며, 이들 radical들의 소거 활성은 Heo et al. (2005)의 결과에서 보고한 상용 항산화제의 radical 소거 활성과 유사한 수준이었다. 한 편, 국내외 (Chosun Daily, 2010; Wolkoff, 2007)에서 이와 같은 감태 추출물의 항산화력은 3 개의 ring 구조를 가진 일반 항산 화물과는 달리 8개의 ring 구조를 가진 일종의 polyphenol 화합 물인 seanol 때문이라고 판단하고, 이를 FDA로 부터 새로운 형태의 기능성 단일 물질로 인증을 받은 다음, 기능성 치약, 샴푸 등이 개발되어 이용되고 있다. 이와 같은 감태 추출물의 seanol 이용 경향으로 미루어 보아 본 감태 추출물의 항산화 활성의 경우도 seanol에 의한 영향이 크리라 판단된다.

감태 효소 추출물의 농도에 따른 Donryu rat liver cell viability를 측정한 결과는 Fig. 2와 같다. t-BHP에 노출시키기 전에 제주산 자생식물 유래 효소 추출물로 전처리한 cell viability는 $25 \mathrm{ug} / \mathrm{mL}$ 에서 $46.4 \%$ 를 나타내었고, 이후 농도 증가 와 더불어 증가하는 경향을 나타내어 $100 \mathrm{ug} / \mathrm{mL}$ 에서 $65.2 \%$ 를 나타내었다.

이상의 시약과 세포를 이용한 항산화 활성의 결과로 미루어 보아 제주산 자생식물 유래 효소 추출물은 높은 radical 소거 활성과 t-BHP에 의한 산화 손상으로부터 Donryu rat liver cell 을 보호할 수 있으리라 판단되어 즉석 국수의 건강 기능성 개선을 위한 천연 항산화제로 이용 가능하리라 추정되었다.

감태 효소 추출물의 배합농도에 따른 헌터 색조

감태 효소 추출물의 첨가 농도를 달리하여 제조한 반죽의 $\mathrm{L}, \mathrm{a}, \mathrm{b}$ 및 $\triangle \mathrm{E}$ value와 같은 Hunter color value를 측정한 결과는 
Table 2. Hunter color value of dough as affected by concentration of enzymatic extract from Ecklonia cava

\begin{tabular}{ccccc}
\hline \multirow{2}{*}{$\begin{array}{c}\text { Concentration } \\
(\%)\end{array}$} & \multicolumn{4}{c}{ Hunter color of dough } \\
\cline { 2 - 5 } & $\mathrm{L}$ & $\mathrm{a}$ & $\mathrm{b}$ & $\triangle \mathrm{E}$ \\
\hline 0 & $76.1 \pm 1.9^{\mathrm{a}}$ & $-1.3 \pm 0.6^{\mathrm{d}}$ & $12.1 \pm 1.4^{\mathrm{d}}$ & $23.8 \pm 2.0^{\mathrm{g}}$ \\
0.3 & $61.7 \pm 0.7^{\mathrm{b}}$ & $3.2 \pm 0.6^{\mathrm{c}}$ & $14.3 \pm 0.4^{\mathrm{bc}}$ & $37.9 \pm 0.6^{\mathrm{f}}$ \\
0.6 & $56.8 \pm 1.1^{\mathrm{c}}$ & $3.8 \pm 0.5^{\mathrm{bc}}$ & $14.9 \pm 0.1^{\mathrm{a}}$ & $42.8 \pm 1.0^{\mathrm{e}}$ \\
0.9 & $53.5 \pm 0.1^{\mathrm{d}}$ & $4.3 \pm 0.2^{\mathrm{b}}$ & $15.0 \pm 0.2^{\mathrm{a}}$ & $45.9 \pm 0.2^{\mathrm{d}}$ \\
1.2 & $49.2 \pm 0.7^{\mathrm{e}}$ & $4.6 \pm 0.7^{\mathrm{ab}}$ & $14.5 \pm 0.5^{\mathrm{abc}}$ & $49.9 \pm 0.6^{\mathrm{c}}$ \\
1.5 & $47.2 \pm 0.6^{\mathrm{f}}$ & $4.9 \pm 0.3^{\mathrm{a}}$ & $14.6 \pm 0.2^{\mathrm{ab}}$ & $51.9 \pm 0.6^{\mathrm{b}}$ \\
1.8 & $45.1 \pm 0.7^{\mathrm{g}}$ & $5.3 \pm 0.2^{\mathrm{a}}$ & $14.0 \pm 0.2^{\mathrm{c}}$ & $53.8 \pm 0.7^{\mathrm{b}}$ \\
2.1 & $43.6 \pm 0.5^{\mathrm{h}}$ & $5.4 \pm 0.2^{\mathrm{a}}$ & $14.2 \pm 0.8^{\mathrm{abcd}}$ & $55.2 \pm 0.5^{\mathrm{a}}$
\end{tabular}

Means with different superscripts in a column are significantly different at $P<0.05$ by Duncan`s multiple range test.

Table 2와 같다. 반죽의 Hunter color value는 감태 효소 추출물 무첨가 반죽의 경우 명도인 $\mathrm{L}$ 값이 76.1 , 적색도인 $\mathrm{a}$ 값이 -1.3 , 황색도인 $\mathrm{b}$ 값이 12.1 및 색차인 $\triangle \mathrm{E}$ 값이 23.8 을 나타내었고, 여기에 감태 효소 추출물을 첨가하는 경우 첨가농도가 증가할 수록 $5 \%$ 유의수준에서 반죽의 명도는 감소하였고, 적색도, 황색도 및 색차는 증가하는 경향을 나타내어, 감태 효소 추출 물 $2.1 \%$ 첨가 반죽의 경우 $\mathrm{L}$ 값이 $43.6, \mathrm{a}$ 값이 $5.4, \mathrm{~b}$ 값이 14.2 및 $\triangle \mathrm{E}$ 값이 55.2를 나타내었다. 한편, Park et al. (2009)은 감태 효소 추출물과 같이 색도를 가진 석류외피 분말을 첨가하여 우리밀 생면을 제조하고자 하는 연구에서 석류외피 분말의 첨가농도가 증가할수록 $\mathrm{L}$ 값이 감소하였고, $\mathrm{a}$ 값 및 $\mathrm{b}$ 값이 증가 하였다고 보고하여 본 실험의 경향과 일치하였다. 감태 효소 추출물의 농도에 따른 색도의 변화는 감태 효소 추출물 특유 의 색도 때문이라 판단되었다. 이상의 감태 효소 추출물의 첨가 농도에 따른 반죽의 색도 결과로 미루어 보아 감태 효소 추출물 첨가 반죽의 색도는 무첨가 반죽의 색도와 확연히 차이가 있어 소비자의 즉석 국수의 선택에 주요한 영향을 미치는 항목 중의 하나가 되리라 판단되었고, 즉석 국수가 항산화성 등과 같은 건강 기능성이 인정되는 경우 차별화에 의하여 소비자들로부터 호응을 받을 수 있으리라 보아진다.

감태 효소추출물의 배합농도에 따른 국수면의 항산 화, 조리 및 관능 특성

감태 효소 추출물의 첨가 농도를 $0-2.1 \%$ 범위로 달리하여 제조한 즉석 국수의 DPPH radical 소거 활성을 살펴 본 결과는 Fig. 3 과 같다. 즉석 국수의 DPPH radical 소거 활성은 감태 효소 추출물 무첨가 시료의 경우 $19.0 \%$ 인데 반하여 감태 효소 추출물 첨가 시료의 경우 $32.2-93.3 \%$ 범위로 $5 \%$ 유의수준에서 확연히 차이가 있었다. 한편, 감태 효소 추출물 첨가 시료 간의 DPPH radical 소거 활성은 감태 효소 추출물 $0.3 \%$ 첨가 시료구의 경우 $32.2 \%$ 를 나타내었고, 이후 감태 효소 추출물의 첨가량이 증가할수록 확연히 증가하여 $1.8 \%$ 첨가한 시료구의 경우 $92.8 \%$ 를 나타내었으며, 그 이상의 시료구 간에는 $5 \%$ 유의수준에서 차이가 없었다.

감태 효소 추출물의 첨가 농도를 달리한 조리 즉석 국수

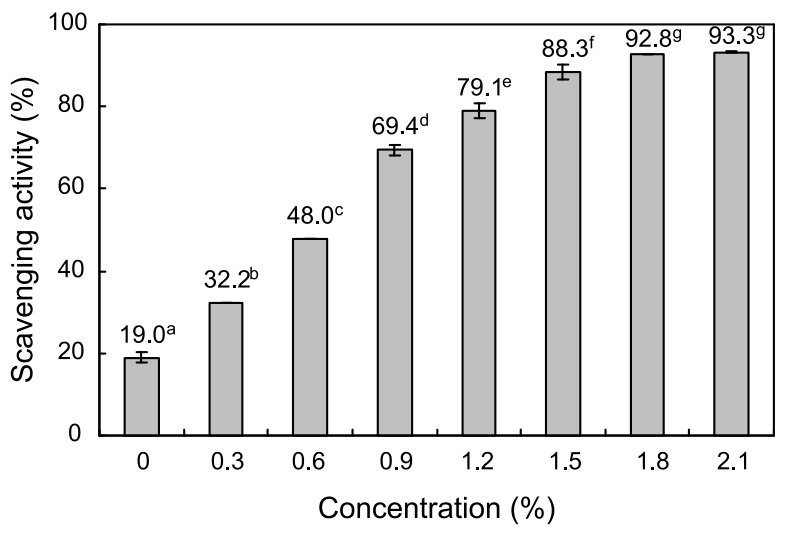

Fig. 3. DPPH radical scavenging activity of instant noodle as affected by concentration of enzymatic extract from Ecklonia cava.

Different letters on the bars indicate a significant difference at $P<0.05$.

Table 3. Weight, volume and water absorption of cooked instant noodle and turbidity of noodle-cooked water as affected by concentration of enzymatic extract from Ecklonia cava

\begin{tabular}{ccccc}
\hline \multirow{2}{*}{$\begin{array}{c}\text { Concentration } \\
(\%)\end{array}$} & \multicolumn{3}{c}{ Cooked instant noodle } & Turbidity \\
\cline { 2 - 4 } & Weight $(\mathrm{g})$ & $\begin{array}{c}\text { Volume } \\
(\mathrm{mL})\end{array}$ & $\begin{array}{c}\text { Water } \\
\text { absorption } \\
(\%)\end{array}$ & $\begin{array}{c}\text { (transmission } \\
\text { at } 660 \mathrm{~nm})\end{array}$ \\
\hline 0 & $18.8 \pm 0.5^{\mathrm{ab}}$ & $17.2 \pm 1.3^{\mathrm{ab}}$ & $87.7 \pm 4.9^{\mathrm{a}}$ & $3.2 \pm 0.1^{\mathrm{e}}$ \\
0.3 & $18.9 \pm 0.3^{\mathrm{ab}}$ & $17.0 \pm 1.0^{\mathrm{b}}$ & $88.7 \pm 3.2^{\mathrm{a}}$ & $57.7 \pm 1.0^{\mathrm{d}}$ \\
0.6 & $18.7 \pm 0.6^{\mathrm{ab}}$ & $19.0 \pm 2.0^{\mathrm{ab}}$ & $87.0 \pm 6.0^{\mathrm{a}}$ & $63.9 \pm 0.7^{\mathrm{c}}$ \\
0.9 & $18.8 \pm 0.6^{\mathrm{ab}}$ & $17.5 \pm 1.0^{\mathrm{ab}}$ & $88.0 \pm 1.0^{\mathrm{b}}$ & $65.3 \pm 0.5^{\mathrm{c}}$ \\
1.2 & $19.3 \pm 0.3^{\mathrm{a}}$ & $17.5 \pm 0.5^{\mathrm{b}}$ & $92.7 \pm 2.5^{\mathrm{a}}$ & $64.3 \pm 5.6^{\mathrm{bcd}}$ \\
1.5 & $19.3 \pm 0.3^{\mathrm{a}}$ & $19.0 \pm 0.5^{\mathrm{a}}$ & $92.7 \pm 2.5^{\mathrm{a}}$ & $70.4 \pm 0.4^{\mathrm{a}}$ \\
1.8 & $18.6 \pm 0.2^{\mathrm{b}}$ & $17.5 \pm 0.5^{\mathrm{b}}$ & $91.0 \pm 2.0^{\mathrm{a}}$ & $73.4 \pm 5.0^{\mathrm{ab}}$ \\
2.1 & $19.2 \pm 0.3^{\mathrm{a}}$ & $18.5 \pm 0.5^{\mathrm{ab}}$ & $91.7 \pm 2.5^{\mathrm{a}}$ & $74.6 \pm 4.5^{\mathrm{a}}$ \\
\hline
\end{tabular}

Means with different superscripts in columns are significantly different at $P<0.05$ by Duncan`s multiple range test.

(숙면에 대하여 3 배의 물을 가하고, 뚜껑을 닫은 다음 3 분간 조리하고 20 초간 냉각 및 1 분간 탈수하여 제조)의 중량, 부피 및 수분 흡수율을 측정한 결과는 Table 3 과 같다. 조리 즉석 국수의 중량 및 부피는 감태 효소 추출물 무첨가 시료가 각각 $18.8 \mathrm{~g}$ 및 $17.2 \mathrm{~mL}$ 인데 반하여, 감태 효소 추출물 첨가 시료가 18.6-19.3 g 범위 및 17.0-19.0\% 범위로 5\% 유의수준에서 차이 가 인정되지 않았다. 또한, 조리 즉석 국수의 중량과 부피는 감태 효소 추출물 첨가 시료구 간에도 큰 차이가 인정되지 않았다. 한편, Park et al. (2006)도 매실 리큐르 제조 부산물인 매실 과육을 국수에 각각 $0 \%, 10 \%, 20 \%$ 및 $30 \%$ 첨가하여 제조한 다음 조리 국수의 중량과 부피를 측정한 결과 중량과 부피는 무첨가 국수와 첨가 국수 간에 미미한 차이가 인정되 었으나, 첨가구 간에는 $5 \%$ 유의수준에서 차이가 인정되지 않았다고 보고한 바 있다. 일반적으로 조리면의 중량과 부피 는 양의 상관관계를 가진다고 알려져 있다 (Park et al., 2006). 이와 같이 본 실험에서 감태 효소 추출물 첨가 즉석 국수의 
부피와 중량이 첨가량에 관계없이 차이가 없었던 것은 첨가 비율이 낮았을 뿐만이 아니라 감태 효소 추출물의 첨가가 gluten의 함량이 낮은 박력분에 대체되었기 때문이라 판단되 었다.

일반적으로 조리 중 수분 흡수도는 전분의 호화나 단백질의 수화에 의하여 진행되며 입자의 크기와도 밀접한 관련이 있다 (Park et al., 2006). 조리 즉석 국수의 수분 흡수도는 감태 효소 추출물 첨가 시료구가 87.0-92.7\% 범위로 무첨가 시료구의 $87.7 \%$ 에 비하여 $5 \%$ 유의수준에서 전혀 차이가 없었다. 또한, 조리 즉석 국수의 수분 흡수도는 $5 \%$ 유의수준에서 감태 효소 추출물 첨가 시료구 간에도 차이가 인정되지 않았다. 이와 같은 결과는 Table 5 에서 언급된 바와 같이 감태 효소 추출물이 보수력에 대한 효과가 인지되지 않았기 때문이라 판단되었다.

조리 중 고형분의 액상으로의 유출 정도를 나타내는 국물의 투과도는 감태 효소 추출물 첨가 즉석 국수의 경우 57.7-74.6\% 범위로 무첨가 즉석 국수의 $3.2 \%$ 에 비하여 훨씬 높았다. 또한, 감태 효소 추출물 첨가 즉석 국수 유래 국물 간의 투과도는 감태 효소 가수분해물 $0.3 \%$ 첨가 즉석 국수가 $57.7 \%$ 를 나타내 었고, 추출물의 농도가 증가할수록 증가하여 $1.5 \%$ 첨가 즉석 국수가 $70.4 \%$ 를 나타내었으며, 그 이상의 농도로 추출물을 첨가하여 제조한 국수의 경우 차이가 없었다. 한편, Lee et al. (2003)은 국수 조리 국물의 탁도의 경우 매실 착즙액의 첨가에 의하여 개선된다고 보고한 바 있다. 일반적으로 국수 의 국물이 탁도가 높다는 것은 고형분의 유출이 많을 뿐만이 아니라 조리된 국수가 쉽게 풀어지고 끊어지기 쉽다는 것을 의미하여 (Kim and Park, 2008), 본 실험에서 감태 효소 추출물 을 첨가한 즉석 국수가 조리 후에도 쉽게 풀어지거나 귾어지 지 않아 보다 양호한 외관과 식감을 유지할 수 있으리라 판단 된다.

감태 효소 추출물 무첨가 조리 즉석 국수를 대조구인 5점으 로 하고, 감태 효소 추출물의 첨가 농도를 달리한 조리 즉석 국수 (숙면에 대하여 3 배의 물을 가하고, 뚜껑을 닫은 다음 3 분간 조리한 시료)의 조직감, 색 및 맛이 이보다 우수한 경우 6-9점을, 그리고 이보다 열악한 경우 4-1점으로 하여 관능검사 를 실시한 결과는 Table 4와 같다. 조리 즉석 국수의 조직감에 대한 관능평점은 감태 효소 추출물 첨가 농도가 증가할수록 우수하였으나, $1.2 \%$ 이상 첨가한 시료구에서 만이 $5 \%$ 유의수 준에서 차이가 인지되었다. 조리 즉석 국수의 색조에 대한 관능평점은 감태 효소 추출물 첨가 농도가 증가할수록 농축물 특유의 암갈색이 인지되어 낮은 관능평점을 받았으나, 감태의 건강 기능성을 인지시킨 뒤 재평가를 실시한 경우 오히려 좋은 평점 (데이타 미제시)을 받았다. 또한, 조리 즉석 국수의 맛에 대한 관능평점은 감태 효소 추출물 첨가 농도에 따른 $5 \%$ 유의수준에서 차이가 인지되지 않았으나 $2.1 \%$ 첨가 시료 구에서는 농축물 특유의 냄새 즉 즉석 국수에 대한 이취가 인지되어 낮은 관능평점을 받았다. 이와 같은 즉석 국수에 대한 관능검사의 결과로 미루어 보아 즉석 국수의 제조를 위한 감태 효소 추출물의 최적 첨가량은 $1.5-1.8 \%$ 범위로 판단 되었다.
이상의 즉석 국수면의 수분 함량, $\mathrm{pH}$ 및 항산화능 (DPPH radical 소거 활성), 조리 즉석 국수의 조리 및 관능 특성 비교의 결과로 미루어 보아 감태 효소 추출물 첨가 즉석 국수의 제조 를 위한 최적 첨가량은 $1.5-1.8 \%$ 범위로 판단되었다.

Table 4. Sensory score on texture, color and taste of cooked instant noodle as affected by concentration of enzymatic extract from Ecklonia cava

\begin{tabular}{clcc}
\hline \multirow{2}{*}{$\begin{array}{c}\text { Concentration } \\
(\%)\end{array}$} & \multicolumn{3}{l}{ Sensory score of cooked instant noodle } \\
\cline { 2 - 4 } & Texture & Color & Taste \\
\hline 0 & $5.0 \pm 0.0^{\mathrm{c}}$ & $5.0 \pm 0.0^{\mathrm{a}}$ & $5.0 \pm 0.0^{\mathrm{a}}$ \\
0.3 & $5.1 \pm 0.8^{\mathrm{bc}}$ & $3.0 \pm 0.0^{\mathrm{b}}$ & $5.0 \pm 0.0^{\mathrm{a}}$ \\
0.6 & $5.4 \pm 0.7^{\mathrm{abc}}$ & $3.0 \pm 0.0^{\mathrm{b}}$ & $5.0 \pm 0.0^{\mathrm{a}}$ \\
0.9 & $5.3 \pm 0.6^{\mathrm{bc}}$ & $3.0 \pm 0.0^{\mathrm{b}}$ & $5.3 \pm 0.7^{\mathrm{a}}$ \\
1.2 & $5.7 \pm 0.6^{\mathrm{ab}}$ & $2.0 \pm 0.0^{\mathrm{c}}$ & $4.7 \pm 0.6^{\mathrm{a}}$ \\
1.5 & $6.0 \pm 0.8^{\mathrm{ab}}$ & $2.0 \pm 0.0^{\mathrm{c}}$ & $5.2 \pm 0.6^{\mathrm{a}}$ \\
1.8 & $6.6 \pm 0.6^{\mathrm{a}}$ & $2.0 \pm 0.0^{\mathrm{c}}$ & $5.7 \pm 0.8^{\mathrm{a}}$ \\
2.1 & $6.3 \pm 0.8^{\mathrm{ab}}$ & $2.0 \pm 0.0^{\mathrm{c}}$ & $2.2 \pm 0.6^{\mathrm{b}}$ \\
\hline
\end{tabular}

Means with different superscripts in columns are significantly different at $P<0.05$ by Duncan's multiple range test.

Table 5. Proximate compositions of instant noodles with and without enzymatic extract from Ecklonia cava

\begin{tabular}{lcccc}
\hline \multirow{2}{*}{ Instant noodle } & \multicolumn{4}{c}{ Proximate composition (g/100 g) } \\
\cline { 2 - 5 } & Moisture & Protein & Lipid & Ash \\
\hline Without extracts & $37.9 \pm 0.1$ & $5.3 \pm 0.0$ & $0.5 \pm 0.0$ & $1.0 \pm 0.0$ \\
With extracts & $38.0 \pm 0.1$ & $5.5 \pm 0.1$ & $0.6 \pm 0.0$ & $1.4 \pm 0.0$ \\
\hline
\end{tabular}

Values are the means \pm standard deviation of three determination.

감태 효소 추출물 첨가 즉석 국수의 일반, 영양 및 항 산화 특성

감태 효소 추출물 $1.5 \%$ 첨가 및 무첨가 즉석 국수의 일반성 분 함량은 Table 5 와 같다. 즉석 국수의 일반성분 함량은 감태 효소 추출물 첨가 시료의 경우 수분 함량이 $38.0 \%$, 조단백질 함량이 $5.5 \%$, 조지방 함량이 $0.6 \%$ 및 회분 함량이 $1.4 \%$ 로, 감태 효소 추출물 첨가 시료의 수분 함량 $37.9 \%$, 조단백질 함량 $5.3 \%$, 조지방 함량 $0.5 \%$ 및 회분 함량 $1.0 \%$ 에 비하여 거의 차이가 없었다. 이와 같은 결과는 즉석 국수의 제조를 위하여 첨가하는 감태 효소 추출물의 비율이 낮으면서 수분 보습력이 높지 않았기 때문이라 판단되었다. 한편, $\mathrm{Kim}$ and Park (2008)은 홍삼을 이용하여 건강 기능성 국수를 제조한 다음 일반성분 함량을 분석한 결과 수분 함량이 33.0-35.5\% 범위, 조단백질이 $7.1-8.0 \%$ 범위, 조지방이 $0.3-0.4 \%$ 범위 및 회분 함량이 1.4-1.6\% 범위이었고, 주성분이 탄수화물이었다 고 보고한 바 있다.

감태 효소 추출물 첨가 및 무첨가 즉석 국수의 총아미노산 함량과 조성을 살펴 본 결과는 Table 6과 같다. 즉석 국수의 총아미노산은 감태 효소 추출물 첨가 유무에 관계없이 두종류 모두가 17 종이 동정되어 차이가 없었다. 즉석 국수의 총아미 
Table 6. Total amino acid (TAA) contents of instant noodles with and without enzymatic extract from Ecklonia cava

\begin{tabular}{|c|c|c|c|c|c|}
\hline \multirow[b]{2}{*}{ Amino acid } & \multicolumn{2}{|c|}{ Instant noodle } & \multirow[b]{2}{*}{ Amino acid } & \multicolumn{2}{|c|}{ Instant noodle } \\
\hline & $\begin{array}{l}\text { Without } \\
\text { extracts }\end{array}$ & $\begin{array}{l}\text { With } \\
\text { extracts }\end{array}$ & & $\begin{array}{l}\text { Without } \\
\text { extracts }\end{array}$ & $\begin{array}{l}\text { With } \\
\text { extracts }\end{array}$ \\
\hline Aspartic acid & $0.20(3.8)^{1)}$ & $0.26(5.1)$ & Methionine & $0.15(2.9)$ & $0.08(1.6)$ \\
\hline Threonine & $0.13(2.5)$ & $0.15(3.0)$ & Isoleucine & $0.64(12.3)$ & $0.15(3.0)$ \\
\hline Serine & $0.20(3.8)$ & $0.25(5.0)$ & Leucine & $0.38(7.3)$ & $0.35(6.9)$ \\
\hline Glutamic acid & $1.26(24.2)$ & $1.69(33.5)$ & Tyrosine & $0.04(0.8)$ & $0.04(0.8)$ \\
\hline Proline & $0.53(10.2)$ & $0.63(12.5)$ & Phenylalanine & $0.20(3.8)$ & $0.30(5.9)$ \\
\hline Glycine & $0.15(2.9)$ & $0.19(3.8)$ & Histidine & $0.08(1.5)$ & $0.11(2.2)$ \\
\hline Alanine & $0.23(4.4)$ & $0.18(3.6)$ & Lysine & $0.08(1.5)$ & $0.13(2.6)$ \\
\hline Cystine & $0.30(5.8)$ & $0.30(5.9)$ & Arginine & $0.11(2.1)$ & $0.16(3.2)$ \\
\hline Valine & $0.52(10.0)$ & $0.08(1.6)$ & Total & $5.20(99.8)$ & $5.05(100.2$ \\
\hline
\end{tabular}

1) The values in parentheses mean $\mathrm{g} / 100 \mathrm{~g}$ amino acids.

Table 7. Mineral contents of instant noodles with and without enzymatic extract from Ecklonia cava

\begin{tabular}{|c|c|c|c|c|c|}
\hline \multirow{2}{*}{$\begin{array}{c}\text { Mineral } \\
(\mathrm{mg} / 100 \mathrm{~g})\end{array}$} & \multicolumn{2}{|c|}{ Instant noodle } & \multirow{2}{*}{ - $\begin{array}{c}\text { Mineral } \\
(\mathrm{mg} / 100 \mathrm{~g})\end{array}$} & \multicolumn{2}{|c|}{ Instant noodle } \\
\hline & $\begin{array}{l}\text { Without } \\
\text { extracts }\end{array}$ & $\begin{array}{c}\text { With } \\
\text { extracts }\end{array}$ & & $\begin{array}{l}\text { Without } \\
\text { extracts }\end{array}$ & With extracts \\
\hline $\mathrm{Ca}$ & $14.9 \pm 0.2$ & $24.0 \pm 0.4$ & $\mathrm{~K}$ & $69.0 \pm 1.3$ & \\
\hline $\mathrm{Fe}$ & $2.2 \pm 0.1$ & $1.9 \pm 0.0$ & $\mathrm{Zn}$ & $3.1 \pm 0.0$ & $3.0 \pm 0.0$ \\
\hline $\mathrm{Mg}$ & $13.0 \pm 0.1$ & $20.9 \pm 0.3$ & $\mathrm{P}$ & $53.5 \pm 0.8 /$ & $54.7 \pm 0.1$ \\
\hline
\end{tabular}

노산 함량은 감태 효소 추출물 첨가 제품이 $5.05 \mathrm{~g} / 100 \mathrm{~g}$ 으로 무첨가 제품의 $5.20 \mathrm{~g} / 100 \mathrm{~g}$ 에 비하여 $2.9 \%$ 가 낮았다. 즉석 국수의 주요 아미노산으로는 감태 효소 추출물 첨가 즉석 국수의 경우 glutamic acid (24.2\%), proline (10.2\%), valine $(10.0 \%)$ 및 isoleucine $(12.3 \%)$ 등과 같은 4종으로, 무첨가 즉석 국수의 경우 glutamic acid (33.5\%) 및 proline (12.5\%) 등과 같은 2종에 비하여 2종이 더 분류되었다. 즉석 국수의 tryptophan을 제외한 9종의 필수아미노산 (threonine, valine, leucine, isoleucine, lysine, methionine, phenylalanine, histidine 및 arginine)은 감태 효소 추출물 첨가 제품이 $43.9 \%$ 로, 무첨가 제품의 $30.0 \%$ 에 비하여 약 $13.9 \%$ 가 높아 영양학적으로는 의 미가 있다고 판단되었다. 감태 효소 추출물 첨가 제품의 필수 아미노산 중 함량 및 조성비가 가장 낮은 아미노산은 histidine 과 lysine으로 두종의 아미노산이 모두 $0.08 \mathrm{~g} / 100 \mathrm{~g}$ 으로, tryptophan을 제외한다면 감태 효소 추출물 첨가 즉석 국수의 제한 아미노산은 histidine과 lysine으로 판단되었다.

감태 효소 추출물 첨가 및 무첨가 즉석 국수의 칼슘, 철, 마그네슘, 칼륨, 아연 및 인과 같은 무기질 함량을 ICP로 분석 한 결과는 Table 7과 같다. 즉석 국수의 무기질 함량은 칼슘의 경우 감태 효소 추출물 첨가 즉석 국수가 $24.9 \mathrm{mg} / 100 \mathrm{~g}$ 으로 무첨가 즉석 국수의 $14.9 \mathrm{mg} / 100 \mathrm{~g}$ 에 비하여 다소 높았고, 인의 경우 감태 효소 추출물 첨가 즉석 국수가 $54.7 \mathrm{mg} / 100$ $\mathrm{g}$ 으로 무첨가 즉석 국수의 $53.6 \mathrm{mg} / 100 \mathrm{~g}$ 과 차이가 없었으며,
마그네슘의 경우 감태 효소 추출물 첨가 즉석 국수가 20.0 $\mathrm{mg} / 100 \mathrm{~g}$ 으로 무첨가 즉석 국수의 $13,0 \mathrm{mg} / 100 \mathrm{~g}$ 에 비하여 높았다. 또한, 칼륨의 경우 감태 효소 추출물 첨가 즉석 국수가 $112.4 \mathrm{mg} / 100 \mathrm{~g}$ 으로 무첨가 즉석 국수의 $69.0 \mathrm{mg} / 100 \mathrm{~g}$ 에 비하 여 높았고, 아연의 경우 감태 효소 추출물 첨가 즉석 국수가 $3.0 \mathrm{mg} / 100 \mathrm{~g}$ 으로 무첨가 즉석 국수의 $3.1 \mathrm{mg} / 100 \mathrm{~g}$ 과 거의 차이가 없었으며, 철의 경우 감태 효소 추출물 첨가 즉석 국수 가 $1.9 \mathrm{mg} / 100 \mathrm{~g}$ 으로 무첨가 즉석 국수의 $2.2 \mathrm{mg} / 100 \mathrm{~g}$ 에 비하여 약간 낮았다. 한편, 위의 무기질에 대한 여러 가지 건강 기능 효과를 기대하기 위한 일일 섭취량으로 Kim et al. (2006)은 칼슘의 경우 $0.6-1.0 \mathrm{~g}$ 범위 (성인의 경우 $0.7 \mathrm{~g}$ ), 마그네슘의 경우 0.2-0.7 g 범위, 인의 경우 0.6-0.9 g 범위 (성인의 경우 $0.7 \mathrm{~g}$ ), 칼륨의 경우 $4 \mathrm{~g}$, 아연의 경우 $15 \mathrm{mg}$ 및 철의 경우 $12 \mathrm{mg}$ 을 제시하였다. 감태 효소 추출물 첨가 즉석 국수 100 $\mathrm{g}$ 을 섭취하는 경우 건강 기능효과를 기대할 수 있는 무기질의 일일 섭취량은 칼슘 (성인 $700 \mathrm{mg}$ 기준)의 경우 $3.4 \%$, 인 (성인 $700 \mathrm{mg}$ 기준)의 경우 $7.8 \%$, 마그네슘 $(500 \mathrm{mg}$ 기준)의 경우 $4.2 \%$, 칼륨의 경우 $2.8 \%$, 아연의 경우 $20 \%$ 및 철의 경우 $15.8 \%$ 에 해당하였다.

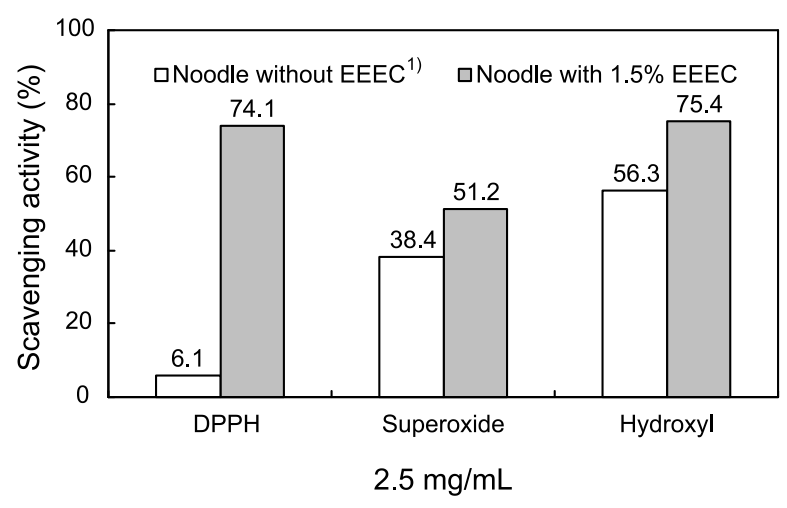

Fig. 4. DPPH free radical scavenging, superoxide anion scavenging and hydroxyl radical scavenging activities of instant noodles with and without enzymatic extract from Ecklonia cava.

1) EEEC : Enzymatic extract from Ecklonia cava

감태 효소 추출물 첨가 및 무첨가 즉석 국수의 항산화성을 DPPH radical, hydroxyl radical 및 superoxide anion radical의 소거 활성으로 살펴 본 결과는 Fig. 4와 같다. 감태 효소 추출물 첨가 효소의 항산화 활성은 hydroxy radical 소거 활성이 $75.4 \%$ 로 가장 우수하였고, 다음으로 DPPH free radical 소거 활성 (74.1\%) 및 superoxide anion radical 소거 활성 $(51.2 \%)$ 의 순이 었다. 반면에 감태 효소 추출물 무첨가 즉석 국수의 항산화 활성은 hydroxy radical 소거 활성이 $56.3 \%$ 로 가장 우수하였고, 다음으로 superoxide anion radical 활성 $(38.4 \%)$ 및 DPPH free radical 소거 활성 $(6.1 \%)$ 의 순이었다. 이와 같은 즉석 국수의 항산화 활성으로 미루어 보아 감태 효소 추출물을 즉석 국수 에 첨가함으로 인하여 항산화 활성이 상당히 개선된 것으로 나타났다. 


$$
\text { 사 사 }
$$

본 연구는 지식경제부 기술개발사업 (제주, 과제번호 7006756-2009-01)의 지원에 의하여 수행되었으며, 이에 감사 드립니다.

$$
\text { 참고문헌 }
$$

AOAC. 1995. Official Methods of Analysis. 16th ed. Association of Official Analytical Chemists, Washington DC. U.S.A. 69-74.

Cha SH, Ahn GN, Heo SJ, Kim KN, Lee KW, Song CB, Cho SM and Jeon YJ. 2006. Screening of extracts from marine green and brown algae in Jeju for potential marine angiotensin-I converting enzyme (ACE) inhibitory activity. J Korean Soc Food Sci Nutr 35, 307-314.

Chong HS and Park CS. 2003. Quality of noodle added powder of Opuntia ficus-indica var. saboten. Korean J Food Preserv 10, 200-205.

Chosun Daily. 2010. http://news.chosun.com/site/data/ htmldir/2010/07/20/ 2010072002175.html

Food News Co. 2009. Food Distribution Yearbook. Food News Co., Seoul, Korea, 205-211.

Guo Q, Zhao B, Shen S, Hou J, Hu J and Xin W. 1999. ESR study on the structure-antioxidant activity relationship of tea catechins and their epimers. Biochimica et. Biophysica Acta 1427, 13-23.

Heo SJ and Jeon YJ. 2005. Antioxidant effect and protecting effect against cell damage by enzymatic hydrolysates from marine algae. Food Ind Nutr 10, 31-41.

Heo SJ, Park, BJ, Lee KW and Jeon YJ. 2005. Antioxidant activities of enzymatic extracts from brown seaweeds. Bioresource Technol 96, 1613-1623.

Kim EM and Park HK. 2008. Quality characteristics of noodles with red ginseng powder add. Korean J Culinary Research 14, 170-180.

Kim EM. 2008. Quality characteristics and shelf-life of rice noodle prepared with red ginseng powder. Korean J Soc Food Sci 14, 161-169.

Kim HR, Hong JS, Choi JS, Han GJ, Kim TY, Kim SB and Chun HK. 2005. Properties of wet noodle changed by the addition of Sanghwang mushroom (Phellinus linteus) powder and extract. Korean J Food Sci Technol 37, 579-583.

Kim JA and Lee JM. 2004. The changes in the chemical components and antioxidant activities in Ecklonia cava according to the drying methods. J Korea Home Economics Asso 42, 193-203.
Kim JS, Kim HS and Heu MS. 2006. Modern Foods. Hyoil Publishing Co, Seoul, Korea. 31-48, 84-91.

Kim ML. 2005. Sensory characteristics of Korean wheat noodles with pine pollen and antioxidant activities of pine pollen extracts. Korean J Soc Food Sci 21, 717-724.

Kwak DY, Kim JH, Choi MS, Shin SR and Moon KD. 2002. Effect of hot-water extract powder from safflower (Carthamus tinctorius L.) seed on quality of noodle. J Korean Soc Food Sci Nutr 31, 460-464.

Lee HA, Nam ES and Park SI. 2003. Effect of maesil (Prunus mume) juice on antimicrobial activity and shelf-life of wet noodle. Korean J Food Culture 18, 428-436.

Lee JH and Shim JY. 2006. Characteristics of wheat flour dough and noodles added with onion juice. Food Engineering Progress 10, 54-59.

Lee JW, Kee HJ, Park YK, Rhim JW, Jung ST, Ham KS, Kim IC and Kang SG. 2000. Preparation of noodle with laver powder and its characteristics. Korean J Food Sci Technol 32, 298-305.

Lee SH, Kim KN, Cha SH, Ahn GN and Jeon YJ. 2006. Comparison of antioxidant activities of enzymatic and methanolic extracts from Ecklonia cava stem and leave. J Korean Soc Food Sci Nutr 35, 1139-1145

Lee YC, Shin KA, Jeong SW, Moon YI, Kim SD and Han YN. 1999. Quality characteristics of wet noodle added with powder of Opuntia ficus-indica. Korean J Food Sci Technol 31, 1604-1612.

Lim YS, Cha WJ, Lee SK and Kim YJ. 2003. Quality characteristics of wet noodle with Lycii fructus powder. Korean J Food Sci Technol 35, 77-83.

Nagayama K, Iwamura Y, Shibata T, Hirayama I and Nakamura, T. 2002. Bactericidal activity of phlorotannins from the brown alga Ecklonia kurome. J Antimicrob Chemoth 50, 889-893.

Nanjo F, Goto K, Seto R, Suzuki M, Sakai M and Hara Y. 1996. Scavenging effects of tea catechins and their derivatives on 1,1-diphenyl-2-picrylhydrazyl radical. Free Radic Bio Med 21, 895-902.

Okai Y, Higashi-Okai K, Ishizaka S, Ohtani K, Matsui-Yuasa I and Yamashita U. 1998. Possible immunodulating activities in an extract of edible brown alga, Hijikia fusiforme (Hijiki). J Sci Food Agric 76, 56-62.

Park BH and Cho HS. 2006. Quality characteristics of dried noodle made with Dioscorea japonica flour. Korean J Soc Food Sci 22, 173-180.

Park CS and Kim ML. 2006. Functional properties of 
mugwort extracts and quality characteristics of noodles added mugwort powder. Korean J Food Preserv 13, 161-167.

Park JH, Kim YO, Gug YI, Jo DB and Choe HG 2003. Effects of green tea powder on noodle properties. J Korean Soc Food Sci Nutr 32, 1021-1025.

Park KD. 1995. A study for dried noodles prepared from composite flours utilizing Job`s tears and wheat flour. Korean J Food Nutr 8, 325-329.

Park KT, Kim MY and Chun SS. 2009. Quality characteristics of Korean wheat wet noodles with pomegranate cortex powder. Korean J Culinary Research 15, 128-136.

Park LY, Chae MH and Lee SH. 2006. Effect of Prunus mume byproduct obtained from liqueur manufacture on quality characteristics of noodles. J Korean Soc Food Sci Nutr 35, 1461-1466.

Park S and Cho EJ. 2004. Quality characteristics of noodle added with chlorella extract. J Food Nutr 17, 120-127.
Rosen GM and Rauckman EJ. 1980. Spin trapping of superoxide and hydroxyl radicals. Method Enzymol 105, 198-209.

Tsutagawa Y, Hosogai Y and Kawai H. 1994. Comparison of mineral and phosphorus contents of muscle and bone in the wild and cultured horse mackerel. J Food Hyg Soc Japan 34, 315-318.

Wolkoff K. 2007. http://www.fibronol.com/SEANOL Science 11-07.pdf

Yasantha A and Jeon YJ. 2005. Screening for angiotensinI converting enzyme inhibitory activity of Ecklonia cava. J Food Sci Nutr 10, 134-139.

2010년 7월 9일 접수

2010년 8월 12일 수정

2010년 10월 12일 수리 